SINAI Journal of Applied Sciences (ISSN: 2314-6079), Vol. (8), Is. (1), Apr. 2019

\begin{tabular}{|c|c|c|}
\hline ; & $\begin{array}{l}\text { sCREENED BY SINAI Journal of Applied Sciences } \\
\text { iThenticate } \\
\text { Professional Plagiarisma Prevention }\end{array}$ & $\overline{\overline{\text { SRU-EGYPT }}}$ \\
\hline
\end{tabular}

\title{
DISTINGUISHING OF ZYGOTIC AND NUCELLAR SEEDLINGS IN CITRUS ROOTSTOCKS USING ISSR TECHNIQUE
}

\author{
Mohamed A. Awad ${ }^{*}$, H.A. El-Alakmy ${ }^{1}$, M.M. Abdalla ${ }^{2}$ and M.D. El-Deeb ${ }^{1}$ \\ 1. Dept. Plant Prod., Fac. Environ. Agric. Sci., Arish Univ., Egypt \\ 2. Dept. Genet., Fac. Agric., Ain Shams Univ., Egypt
}

\begin{abstract}
The objective of this study is to evaluate the morpho-based method (common system) which used to distinguish between zygotic seedling and nucellar seedling of Cleopatra mandarin and Sour orange rootstocks using ISSR technique. Eight ISSR primers were used to check true-to-type of three mother-plants and nine seedlings of two citrus species, Cleopatra mandarin from Giza nursery and Sour orange from Benha nursery. Results showed that ISSR markers were a utility to identify nucellar or zygotic seedlings and check seedlings true to the type of mother plant. Three Cleopatra mandarin seedlings (33.3\%) were identified as nucellar seedlings and six seedlings $(66.7 \%)$ were identified as zygotic seedlings when using ISSR5 primer. While this percentages were different when using ISSR5 primer with Sour orange seedlings, which revealed one of them $(11.1 \%)$ was identified as a nucellar seedling and eight seedlings $(88.8 \%)$ were identified as zygotic seedlings. This suggested that the common method used until now for selection the nucellar seedlings in nursery is not perfect. Finally, that screening of seedlings for early identification of putative zygotic seedlings by ISSR analysis for random and various combinations is essential in citrus to maintain the genetic characteristics of the citrus rootstocks in orchards.
\end{abstract}

Key words: Genetic variability, ISSR markers, citrus rootstocks, zygotic seedlings, nucellar seedlings.

\section{INTRODUCTION}

Citrus is a very important economic crop in Egypt with a production of 4,646,579 metric tons (Mt) on 1,070,478 hectares according to the Yearly of Statistic and Agricultural Economic Dept. (2015). The citrus cultivated depend on the rootstocks used which play a key role for better growth and production (Garcia-Sanchez et al., 2003). In Egypt, Sour orange is using extensively, and recently Volkamer lemon is more widely used in sandy soils regions (Salem and Sheta, 2002). Theses rootstocks are produced by different methods but the optimum methods by seeds. But seeds of many important citrus cultivars produce zygotic embryos as well as nucellar embryony which consider as

\footnotetext{
* Corresponding author: Tel.: +201012562461

E-mail address: smallgenusawad@yahoo.com
}

unique botanical feature (Frost and Soost, 1968). Nucellus cells grow much more vigorously than the zygotic embryos and develop growers genetically identical to mother plant (Xu et al., 2013).

This botanical feature due to variation between citrus species trees in orchards in resistance unfavorable factors such as abiotic factors: drought, flooding, salinity, mineral deficiency and toxicity, metal toxicity, heat, cold, soil temperature, $\mathrm{pH}$, etc., and biotic factors such as, plant diseases, insects and nematodes (Louws et al., 2010; Ghrab et al., 2014; Castle et al., 2016). So, the differentiation between seedlings develops by zygotic embryos or nucellar embryony as early in nursery is the very important agricultural practices before 
transferring these seedlings to the orchards. But up to now, the farmer finds difficulty to distinguishing zygotic from nucellar seedling.

Now a days, the morphological method still a common practice in nursery until now to distinguish zygotic from nucellar seedlings. However, it is very difficult to identify both the nucellar and zygotic seedlings (Kumar and Rani, 2013). The plant breeder keeps on the zygotic plantlets and remove the nucellar ones produced from the same seed by some morpho-traits such as: the zygotic plantlets were generally weak than nucellar plantlets, but it's strongest in growing compared with nucellar embryos when the zygotic embryos are still survival (El-Hamady $\boldsymbol{e t}$ al., 2009). Hence, this practice is effective in removing some zygotic plantlets, but not all (Ruiz et al., 2000).

Fortunately, the molecular markers are considered important tools to detect higher level of polymorphism between samples. Among these markers the inter-simple sequence repeats (ISSR) that is effective to study genetic diversity between different citrus rootstocks species in many citrus genetic studies (Fang and Roose, 1997; Liang et al., 2007; Shahsavar et al., 2007). So, the aim of present study is to evaluate the morpho-based method (common system) which used to distinguish between zygotic seedling from nucellar seedling of Cleopatra mandarin and Sour orange using ISSR technique.

\section{MATERIALS AND METHODS}

\section{DNA Extraction}

Nine samples from seedlings and three mother-plants of two citrus species; Cleopatra mandarin from Giza nursery and Sour orange from Benha nursery, Egypt were used. DNA was obtained from young healthy leaves for mother-trees and seedlings by grinding them with $750 \mu$ of preheated $\left(65^{\circ} \mathrm{C}\right)$ extraction buffer which contained
2\% hexadecyltrimethylammonium bromide [CTAB], $\quad 1.4 \quad \mathrm{M} \quad \mathrm{NaCl}, \quad 0.2 \% \quad 2-$ mercaptoethanol, $20 \mathrm{mM}$ EDTA, and 100 $\mathrm{mM}$ Tris-HCl, $\mathrm{pH}$ 8.0. Mixtures were incubated at $60^{\circ} \mathrm{C}$ for 30 minutes, then extraction procedure was completed with Genomic Plant Kit (Zymo scientific Inc., USA) by following the manufacturer's instructions. The DNA quality checked with electrophoresis by agarose gel $1 \%(W / V)$. After quality check, DNA was taken to perform genetic analysis.

\section{ISSR Analysis}

A $25 \mathrm{ml}$ of PCR reaction mixture contained a 0.25 unit of Taq DNA polymerase; $5 \mu 1$ PCR buffer $1 \mathrm{x} ; 2.5 \mu \mathrm{l}$ primer and DNA sample (200 ng) to each sample tube. The reaction was performed in a PCR thermocycler with 35 cycles, each consisting of $1 \mathrm{~min}$ at $94^{\circ} \mathrm{C}, 1 \mathrm{~min}$ at annealing temperature $\left(40^{\circ} \mathrm{C}\right)$, and an extension step of $2 \mathrm{~min}$ at $72^{\circ} \mathrm{C}$. After 35 cycles, a final step of $7 \mathrm{~min}$ at $72^{\circ} \mathrm{C}$ was allowing to complete the synthesis of DNA strands. Eight ISSR primers were used (Table 1). Amplification products were analyzed by electrophoresis on $1.5 \%$ agarose gels, buffered with $1 \mathrm{x}$ TAE and stained with ethidium bromide $(\mathrm{EtBr})$. The fragments were visualized using ultraviolet (UV) light source. Fragments were detected using TotalLab-120 software (Nonlinear Dynamics, USA) according to software manual. fragments were scored as 1 (present) or 0 (absent). Then, the principal coordinate analysis (PCoA) was carried out.

\section{RESULTS AND DISCUSSION}

Three mother-trees $\left(\mathrm{P}_{1}, \mathrm{P}_{2}\right.$, and $\left.\mathrm{P}_{3}\right)$ and nine seedlings $\left(\mathrm{S}_{1}, \mathrm{~S}_{2}, \mathrm{~S}_{3}, \mathrm{~S}_{4}, \mathrm{~S}_{5}, \mathrm{~S}_{6}, \mathrm{~S}_{7}, \mathrm{~S}_{8}\right.$ and $\mathrm{S}_{9}$ ) of two citrus species, Cleopatra mandarin from Giza nursery and Sour orange from Benha nursery were screened.

Results showed that RAMP-GAC and ISSR5 primers were selected among all ISSR primers according to their polymorphic patterns between the Cleopatra mandarin 
Table (1): List of ISSR primers used in this study

\begin{tabular}{lll}
\hline No. & Primer & Primer sequence (5' 3') \\
\hline $\mathbf{1}$ & ISSR11 & $5^{\prime}[\mathrm{AG}]_{8} \mathrm{GT} 3^{\prime}$ \\
$\mathbf{2}$ & ISSR7 & $5^{\prime}[\mathrm{GA}]_{8} \mathrm{~T} 3^{\prime}$ \\
$\mathbf{3}$ & LK7 & $5^{\prime} \mathrm{CCA}[\mathrm{CT}]_{8} 3^{\prime}$ \\
$\mathbf{4}$ & RAMP-GAC & $5^{\prime} \mathrm{G}[\mathrm{AC}]_{9} 3^{\prime}$ \\
$\mathbf{5}$ & ISSR5 & $5^{\prime}[\mathrm{AG}]_{8} \mathrm{~T} 33^{\prime}$ \\
$\mathbf{6}$ & RAMP-TAG & $5^{\prime} \mathrm{T}[\mathrm{AG}]_{9} 3^{\prime}$ \\
$\mathbf{7}$ & ISSR14 & $5^{\prime}[\mathrm{CA}]_{8} \mathrm{GG} 3^{\prime}$ \\
$\mathbf{8}$ & ISSR8 & $5^{\prime}[\mathrm{CT}]_{8} \mathrm{G} \mathrm{3} 3^{\prime}$ \\
\hline
\end{tabular}

mother-trees and their seedlings (Fig. 1). Gel pattern of RAMP-GAC primer (Fig. 1A) observed that three seedlings $\left(\mathrm{S}_{2}, \mathrm{~S}_{4}\right.$ and $\mathrm{S}_{7}$ ) were identified as zygotic seedlings by the absent of three fragments from $\mathrm{S}_{2}$ individual $(577,631$ and $697 \mathrm{bp}$ ), four fragments from S4 individual $(631,697$, 852 and $1023 \mathrm{bp}$ ) and three fragments from $\mathrm{S}_{7}$ individual $(631,697$ and $771 \mathrm{bp})$, which was presented in each of mother-trees and the other six seedlings. In addition, ISSR5 primer detected six seedlings $\left(\mathrm{S}_{4}, \mathrm{~S}_{5}, \mathrm{~S}_{6}, \mathrm{~S}_{7}\right.$, $\mathrm{S}_{8}$ and $\mathrm{S}_{9}$ ) as zygotic seedlings by the presence of $1449 \mathrm{bp}$ fragment which was absent in mother-trees and the other three seedlings (Fig. 1-B). Also, no difference was found among each of the mother-trees with the both primers.

The principal coordinate analysis (PCoA) result divided the 12 individuals into three clusters (Fig. 1-C). The three mother-trees $\left(\mathrm{P}_{1}, \mathrm{P}_{2}\right.$ and $\left.\mathrm{P}_{3}\right)$ were grouped together in cluster I with two seedlings $\left(\mathrm{S}_{1}\right.$ and $\left.\mathrm{S}_{3}\right)$. But $\mathrm{S}_{2}$ and $\mathrm{S}_{7}$ seedlings were tended to cluster together into cluster II. While the five remaining seedlings $\left(\mathrm{S}_{4}, \mathrm{~S}_{5}, \mathrm{~S}_{6}, \mathrm{~S}_{8}\right.$ and $\left.\mathrm{S}_{9}\right)$ were clustered into cluster III. This PCoA graph indicted that $\mathrm{S}_{1}$ and $\mathrm{S}_{3}$ seedlings had the same genetic structure of the mothertrees which could be produced from nuclear embryo. In contrast, the other seedlings into the two different clusters were attest the variability of their genetic background compared with their mother-trees which could be produced from zygotic embryo or pollinated from another citrus species.

On the other hand, ISSR5 primer detected one nucellar seedling of Sour orange $\left(\mathrm{S}_{1}\right)$ compared with two mother-trees $\left(\mathrm{P}_{1}\right.$ and $\left.\mathrm{P}_{2}\right)$ pattern (Fig. 2-A). But $\mathrm{P}_{3}$ mother-plant have one additional fragment (353 bp) not showed with other mother-plants, that make $\mathrm{P}_{3}$ mother plant is a different genetic structure. And this was confirmed with RAMP-TAG primer by not having two fragments (970 and $1096 \mathrm{bp}$ ) in its pattern (Fig. 2-B). But RAMP-TAG primer identified five seedlings only $\left(\mathrm{S}_{2}, \mathrm{~S}_{3}, \mathrm{~S}_{4}, \mathrm{~S}_{6}\right.$ and $\left.\mathrm{S}_{7}\right)$ as zygotic seedlings because the two fragments (970 and $1096 \mathrm{bp}$ ) don't show in its pattern.

This genetic diversity was shown in the principal coordinate analysis (PCoA) resulting. The 12 individuals of sour orange were clustered into five clusters (Fig. 2-C). The two mother-trees $\left(\mathrm{P}_{1}\right.$ and $\left.\mathrm{P}_{2}\right)$ grouped together in the same cluster with three seedlings $\left(\mathrm{S}_{1}, \mathrm{~S}_{5}\right.$ and $\left.\mathrm{S}_{8}\right)$. While each of $\mathrm{P}_{3}$ mother-trees and $\mathrm{S}_{6}$ and $\mathrm{S}_{9}$ seedlings separated into three clusters. But $\mathrm{S}_{2}, \mathrm{~S}_{3}, \mathrm{~S}_{4}$ 


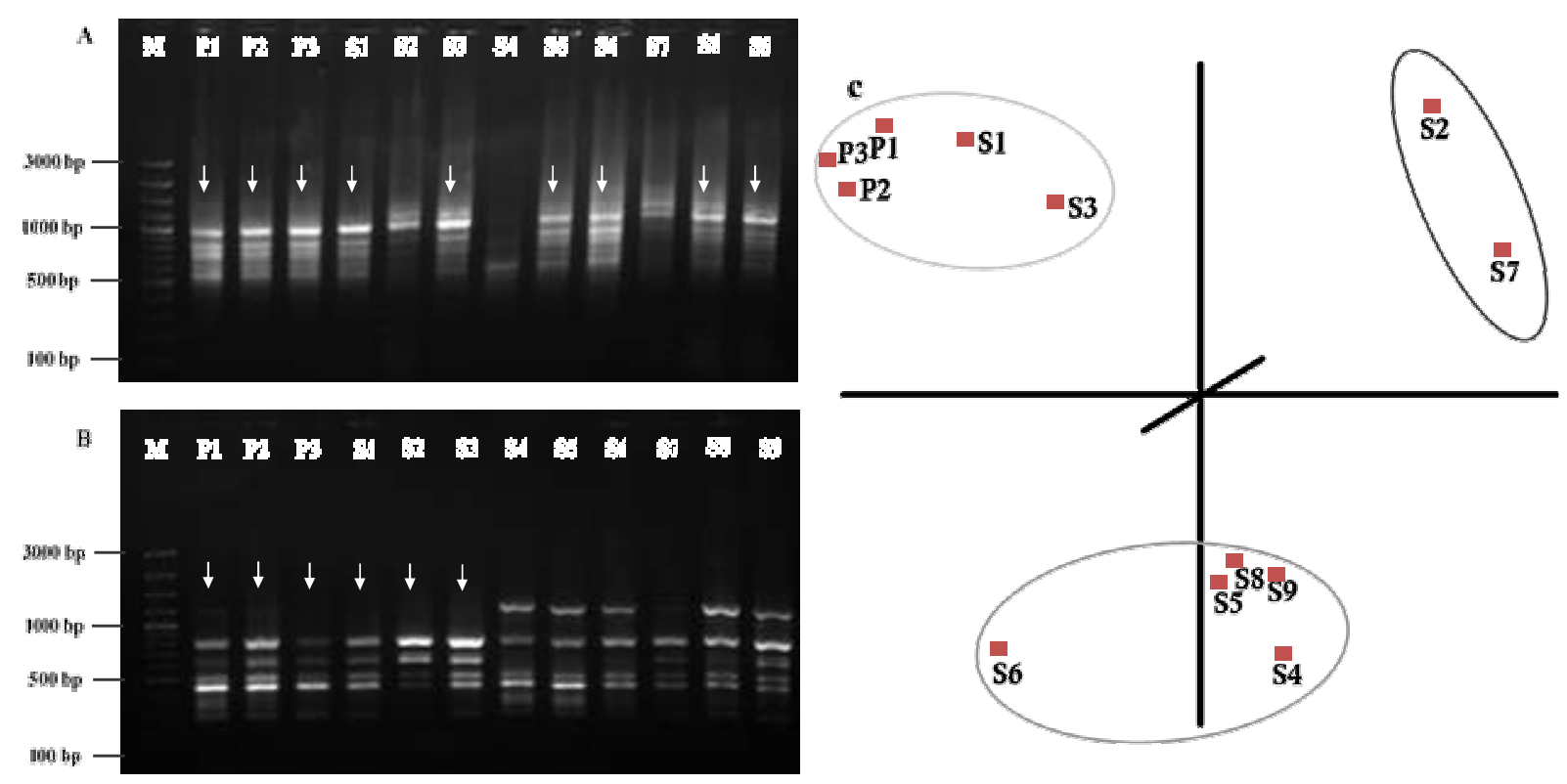

Fig. (1): ISSR amplification patterns to three Cleopatra mandarin mother-trees and their nine seedlings. (P), (S) and (M) refer to mother-plants, seedlings, and 100 bp ladder molecular marker, respectively.
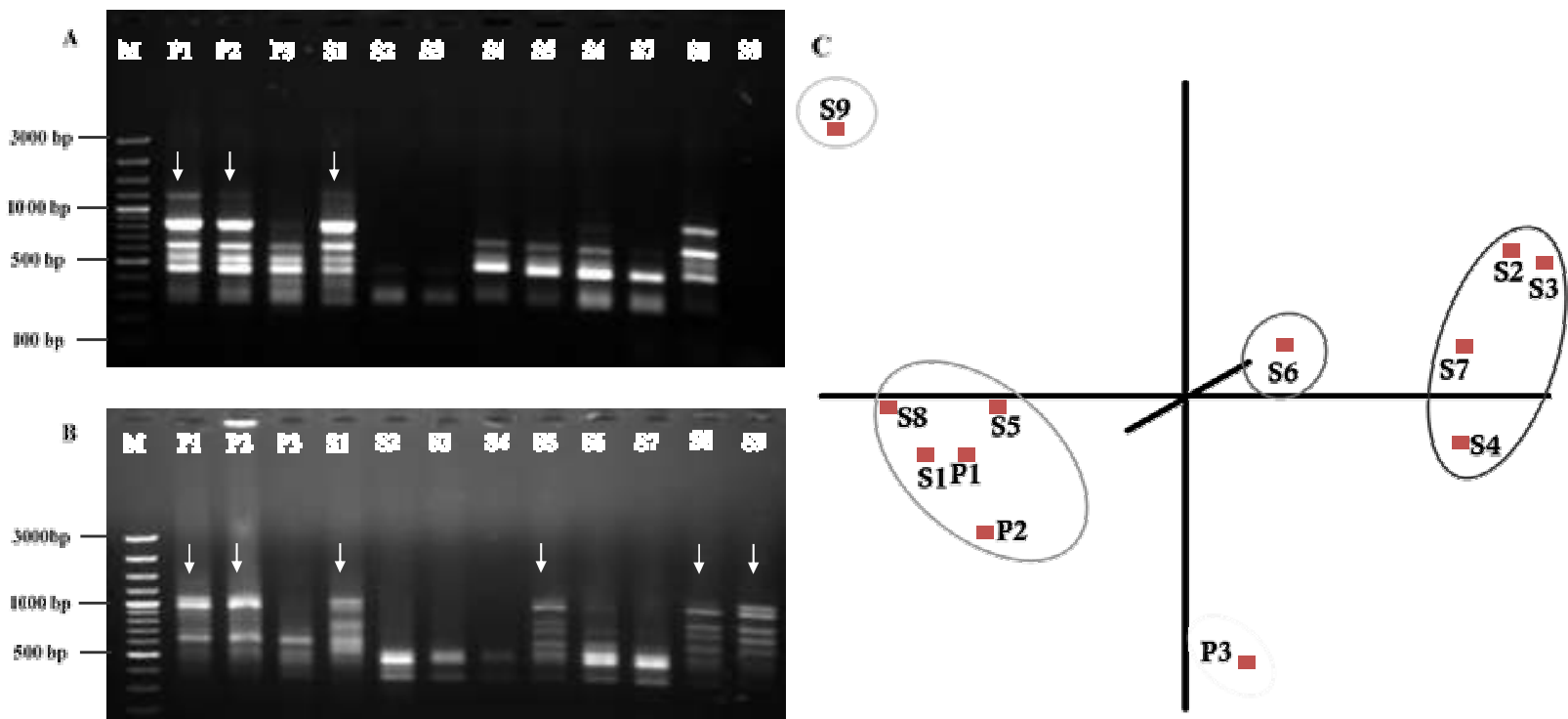

Fig. (2): ISSR amplification patterns to three Sour orange mother-trees and their nine seedlings. (P), (S) and (M) refer to mother-plants, seedlings, and 100 bp ladder molecular marker, respectively. 
and $S_{7}$ tend to cluster together into cluster V. Depending upon this PCoA results, it's certainly found the $\mathrm{P}_{1}$ and $\mathrm{P}_{2}$ mother- trees with $\mathrm{S}_{1}, \mathrm{~S}_{5}$ and $\mathrm{S}_{8}$ individuals attest that these seedlings have the same genetic structure and produced from nuclear embryo. On the other hand, separate the other parent $\left(\mathrm{P}_{3}\right)$ and five seedlings into four different clusters refer to the genetic variability was differed from the mothertrees which could be produced from zygotic embryo or pollinated from another citrus species.

In brief, these results noticed that three Cleopatra mandarin seedlings $(33.3 \%)$ were identified as nucellar seedlings and six seedlings $(66.7 \%)$ as zygotic seedlings using RAMP-GAC primer. While this percentages were different with using ISSR5 primer which identified three seedlings $(33.3 \%)$ as nucellar seedlings and six seedlings $(66.7 \%)$ as zygotic seedlings. But, Sour orange seedlings revealed one of them $(11.1 \%)$ as nucellar seedling and eight seedlings $(88.8 \%)$ as zygotic seedlings using ISSR 5 primer. While this percentages were changed when using RAMP-TAG primer which identified three seedlings $(33.3 \%)$ as nucellar seedlings and six seedlings $(66.7 \%)$ as zygotic seedlings. This finding agree with Kashyap et al. (2018) who recognized $37(53.6 \%)$ as zygotic and $32(46.3 \%)$ as nucellar Khasi mandarin (Citrus reticulata Blanco) seedlings among 69 tested individuals, using four ISSR and three RAPD primers. Xiang and Roose (1988) reported that in Taiwanica sour orange, greater than a $30 \%$ of seedlings from polyembryonic seeds were classified as zygotic seeds. Consequently, ISSR markers are a utility to identify nucellar or zygotic seedlings and check seedlings true-to-type of mother plant.

These results revealed that the embryo type which developed seedlings were variable in the same nursery, some of seedlings were divided from a nucellar embryo and the other from a zygotic embryo. These lead to a difference in genetic structure among the same species seedlings in nurseries. It is known that the seedling developed from a nucellar embryo is genetically similar to the parent seed, whilst a zygotic embryo is different from parent seed (Ollitrault and Navarro 2012; Khan et al., 2017) This consider as major problem to citrus growers due to a different orchard in horticultural performance, e.g. growth and characteristics of fruit (Cordeiro et al., 2006; Rao et al., 2008). Finally, this result suggested that screening of seedlings for early identification of putative zygotic seedlings by ISSR analysis of random and various combinations of seedlings is essential in citrus to guarantee the origin of these seedlings. ISSR5 primer is a strong tool to distinguish between zygotic seedling from nucellar seedling of Cleopatra mandarin and Sour orange.

\section{REFERENCES}

Castle, W.S.; Bowman, K.D.; Grosser, J.W.; Futch, S.H. and Graham, J.H. (2016). Florida Citrus rootstock selection guide $\left(3^{\text {rd }}\right.$ Ed.). UF/IFAS Extension Service, University of Florida.

Cordeiro, M.C.R.; Pinto, A.C.Q.; Ramos, V.H.V.; Faleiro, F.G. and Fraga, L.M.S. (2006). Identificação da origem genética de plântulas em sementes poliembriônicas de mangueira (Mangifera indica L.) cv. Rosinha por meio de marcadores RAPD. Revista Brasileira de Fruticultura, 28: 454-457.

El-Hamady, M.A.; Salem, S.E. and El-Hamady, A.M. (2009). Citrus: production and improvement genetic. Scientific Book House, $1^{\text {st }}$ Ed., 286-342.

Fang, D.Q. and Roose, M.L. (1997). Identification of closely related citrus cultivars with inter-simple sequence repeat markers. Theor. Appl. Genet., 95: 408-417. 
Frost, H.B. and Soost, R.K. (1968). Seed reproduction: Development of gametes and embryos, In: W. Reuther, L.D. Batchelor, and H.J. Webber (eds.). The citrus industry. Univ. Calif. Press, Riverside, 2: 290-324.

Garcia-Sanchez, F.; Carvajal, M.; Cerda, A. and Martinez, V. (2003). Response of star ruby grapefruit on two rootstocks to $\mathrm{NaCl}$ salinity. Hort. Sci. Biotechnol., 78: 859-865.

Ghrab, M.; Mimoun, M.B.; Masmoudi, M.M. and Mechlia, N.B. (2014). Chilling trends in a warm production area and their impact on flowering and fruiting of peach trees. Scientia Hort., 178: 87-94.

Kashyap, K.; Banu, S.; Shrivastava, M.N. and Ramchiary, N. (2018). Study of polyembryony and development of molecular markers for identification of zygotic and nucellar seedlings in Khasi mandarin (Citrus reticulata Blanco). IJEAB, 3 (2): 363- 372.

Khan, M.M.; Al-Yahyai, R. and Al-Said, F. (2017). The Lime: Botany, Production and Uses. CAB Int., Boston, MA, 13-28.

Kumar, K. and Rani, U. (2013). Techniques to differentiate zygotic and nucellar seedlings in polyembryonic fruit crops. Int. J. Agric., Environ. and Biotechnol., 6 (3): 344-350.

Liang, G.; Xiong, G.; Guo, Q.; He, Q. and $X$. Li (2007). AFLP Analysis and the taxonomy of citrus. Acta Hort., 760: 137-143.

Louws, F.J.; C.L. Rivard and C. Kubota (2010). Grafting fruiting vegetables to manage soilborne pathogens, foliar pathogens, arthropods and weeds. Scientia Hort., 127: 127-146.

Ollitrault, P. and Navarro, L. (2012). Citrus. In: Fruit Breeding. M.L. Badenes and D.H. Byrne (eds.), Handbook of Plant Breeding 8, Springer Sci., LLC, 623-662.

Rao, M.N.; Soneji, J.R.; Chen, C.; Huang, S. and Gmitter, Jr. F.G. (2008). Characterization of zygotic and nucellar seedlings from sour orange-like citrus rootstock candidates using RAPD and EST-SSR markers. Tree Genet. and Genomes, 4: 113-124.

Ruiz, C.; Paz Breto, M. and Asins, M.J. (2000). A quick methodology to identify sexual seedlings in citrus breeding programs using SSR markers. Kluwer Acad. Publishers, 112: 89-94.

Salem, S.E. and Sheta, I. (2002). Citriculture and genetic resources in Egypt: state of the art. In: D 'Onghia A.M. (Ed.), Djelouah K. (ed.), Roistacher C.N. (Ed.). Proceedings of the Mediterranean research network on certification of citrus (MNCC): 1998-2001. Bari: CIHEAM, pp. 27-29. Options Méditerranéennes: Série B. Etudes et Recherches; No. 43).

Shahsavar, A.R.; Izadpanah, K.; Tafazoli, E. and Tabatabaei, B.E.S. (2007). Characterization of citrus germplasm including unknown variants by intersimple sequence repeat (ISSR) markers. Scientia Hort., 112: 310-314.

Xiang, C. and Roose, M.L. (1988). frequency and characteristics of nucellar and zygotic seedlings in 12 citrus rootstocks. Scientia Hortic., 37: 47-59.

Xu, Q.; Chen, L.; Ruan, X.; Chen, D.; Zhu, A.; Chen, C. and Bertrand, D. (2013). The draft genome of sweet orange (Citrus sinensis). Nature Genet., 45 (1): 59-68.

Yearly of Statistic and Agricultural Economic Dept. (2015). Ministry of Agric. and Reclamation. Egypt. 
SINAI Journal of Applied Sciences (ISSN: 2314-6079), Vol. (8), Is. (1), Apr. 2019

تمييز الثتّلات الجنسية والنيوسيلية في أصول الموالح باستخدام واسمات التتابعات البينية البسيطة المتكررة المورة

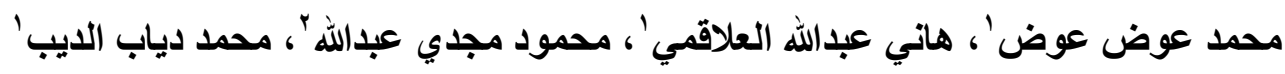

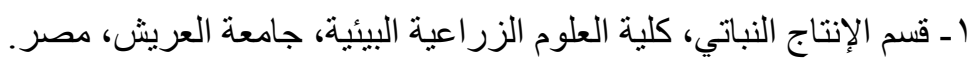

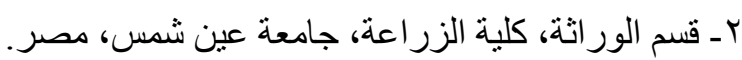

يهذف هذا العمل إلى تقييم استخدام الطريقة المورفولوجية (الطريقة الثائعة) للتمييز بين الثنتلات الجنسية و النيوسيلية

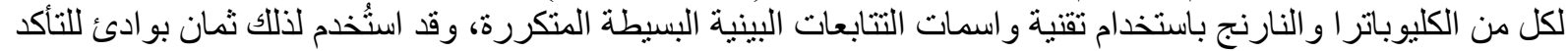

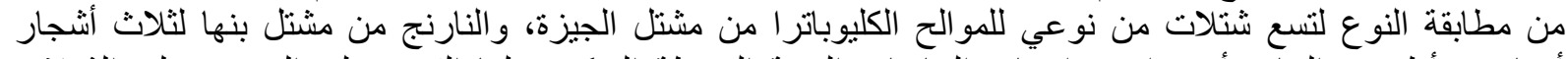

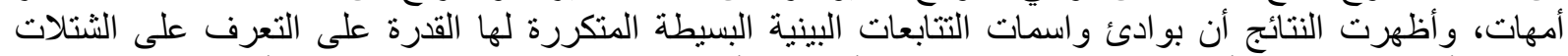

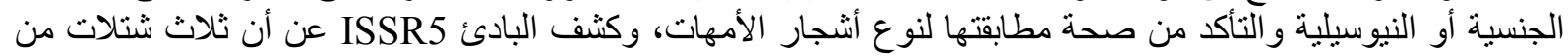

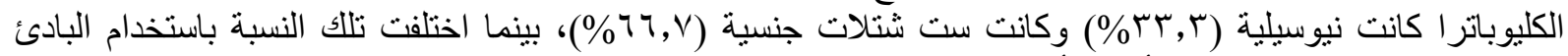

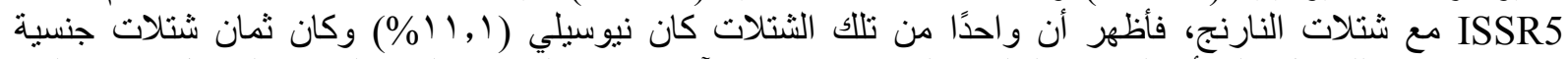

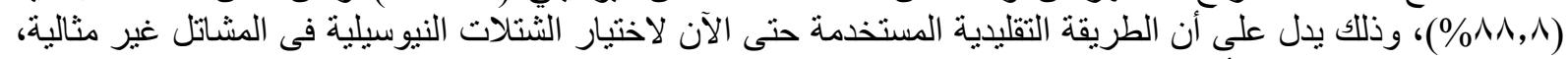

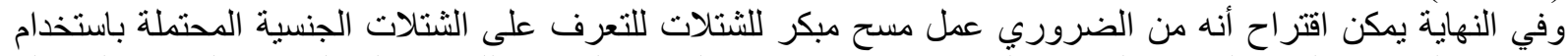

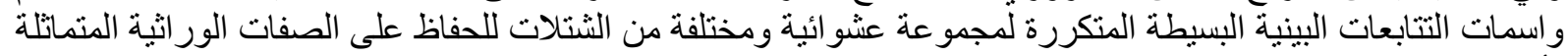
لأصول المو الح بالبستان.

الكلمات الإسترشادية: التباين الوراثي، واسمات التتابعات البينية البسيطة المتكررة، أصول الموالح، الثتلات الجنسية، الثتلات النيوسيلية.

أستاذ الور اثة، كلية الزر اعة، جامعة عين شمس، مصر. أستاذ الفاكهة المساعد، كلية العلوم الزراعية البرائة البيئية، جامعة العريش، مصر.

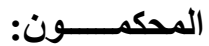

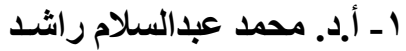
r ـ د. محمد أحمد محمد نجاتي 
